\title{
PHENYLUREA-TYPE CYTOKININ AMELIORATES THE PERFORMANCE OF YOUNG PEA PLANTS UNDER SALT STRESS
}

\section{Irina Moskova, Konstantina Kocheva*}

Bulgarian Academy of Sciences, Institute of Plant Physiology and Genetics, Acad. G. Bonchev Str. 21, 1113 Sofia, Bulgaria

*Corresponding author. E-mail: konstvk@abv.bg

\begin{abstract}
Moskova I., Kocheva K., 2021: Phenylurea-type cytokinin ameliorates the performance of young pea plants under salt stress. - Botanica, 27(2): 141-148.

Cytokinins are known to enhance stress tolerance in plants. The present study aimed to assess the possible protective effect of exogenous phenylurea-type cytokinin (4PU-30) on alleviating salt ( $\mathrm{NaCl}$ ) stress. Young pea (Pisum sativum L.) plants were sprayed with cytokinin 4PU-30 and were subsequently subjected to $\mathrm{NaCl}$ treatment. The effect of 4PU-30 on cell membrane stability was assessed based on electrolyte leakage from leaves of control and $\mathrm{NaCl}$ stressed plants. A previously established model system employing the kinetics of ion leakage served to evaluate the effect of the 4PU-30 application on plants response to salinity. Salt treatment caused a moderate decrease in leaf water content. Accumulation of proline, malondialdehyde (MDA), and hydrogen peroxide $\left(\mathrm{H}_{2} \mathrm{O}_{2}\right)$ in the leaves of $\mathrm{NaCl}$ treated plants indicated the development of oxidative stress, which was significantly alleviated by pretreatment with phenylurea-type cytokinin 4PU-30. Foliar application of 4PU-30 reduced the damaging effect of $\mathrm{NaCl}$, as evidenced by decreased electrolyte leakage. Distinct roles of cell walls and plasmalemma in the processes of ion efflux due to salt stress are discussed.
\end{abstract}

Keywords: cytokinins, electrolyte leakage, hydrogen peroxide, malondialdehyde, NaCl, Pisum sativum L.

\section{INTRODUCTION}

Salt $(\mathrm{NaCl})$ content in soils is one of the most critical global problems that negatively affect crop plants' growth rates and productivity. High salinity causes both ionic and osmotic stress (ISAYENKOV, 2012). Thus, salinity impairs plant growth and development via water deficiency stress, cytotoxicity due to excessive uptake of ions such as sodium $\left(\mathrm{Na}^{+}\right)$and chloride $\left(\mathrm{Cl}^{-}\right)$, and nutritional imbalance. In addition, salinity is typically accompanied by oxidative stress due to the generation of highly reactive chemicals formed from $\mathrm{O}_{2}$, which are recognised as reactive oxygen species (ROS) (IsAYENKov, 2012; DemidChiK, 2015; JAJIC et al., 2015).

Overcoming the damaging effect of various stress factors could be achieved through the application of plant growth regulators. The practical and straight- forward approach allows adequate and duly reaction under harmful circumstances (GIRON et al., 2013). Cytokinins (CKs) are key phytohormones that regulate plant growth and development and mediate plant tolerance to stress (Liu et al., 2020; Yu et al., 2020). There is evidence in the literature that CKs can have both positive and negative functions in the adaptation of plants to stress (Veselov et al., 2017; HaI et al., 2020). It was shown that slightly increased cytokinin levels could enhance stress tolerance to various abiotic stresses and impact yield in a wide variety of plants (Guo \& GAN, 2014). Applying some phenylureas enhance the stress tolerance of plants subjected to salinity (SÁ et al., 2020). Phenylurea-type cytokinin 4PU-30 (N1-(2-chloro-4-pyridyl)-N2phenylurea) was described to alleviate the negative consequences of drought (Todorov et al., 1998) and high-temperature stress (YORDANOv et al., 1997) and 
to mitigate the detrimental effects of glyphosate (SERGIEV et al., 2006). Treatment with cytokinins was also shown to increase plant tolerance to viruses (GIRON et al., 2013). In a previous investigation, we found that 4-PU-30 treatment of tomato plants infected with TSWV had an inhibitory effect on viruses and reduced the adverse effects of oxidative stress caused by the pathogen (Moskova et al., 2020).

Pea (Pisum sativum L.) is a vital legume crop worldwide and represents a significant protein supply for the human diet, and salinity causes yield reductions in many regions. Membranes are among the first stress targets (ELBASYONI et al., 2017). Assessment of membrane integrity is often realised through the measurement of electrolyte leakage from plant tissues. Employing the new kinetic approach through multiple time-points measurements offer the advantage of distinguishing ion fluxes through different cellular compartments (Kocheva et al., 2014). The separation of ion fluxes through cell walls and membranes can be based on the different rates of ion movement through separate cellular compartments. The diffusion model argued that ion efflux across cell walls might also be changed under stress and diffusion across the membrane.

This study aimed to assess the possible effect of cytokinin 4PU-30 pretreatment on the response of young pea plants to salt $(\mathrm{NaCl})$ stress.

\section{MATERIALS AND METHODS}

Plant material, growing conditions and treatments. Two independent experiments were carried out in 2018 and 2019. Seedlings of Pisum sativum L. were grown on a half-strength Hoagland-Arnon nutrition medium in a growth chamber under the following conditions: $12 / 12 \mathrm{~h}$ photoperiod; the light intensity of $70 \mu \mathrm{mol} \mathrm{m} \mathrm{m}^{-1}$, temperature $25 \pm 1^{\circ} \mathrm{C}$. Ten-day-old seedlings were sprayed with water solution of $1 \times 10^{-6} \mathrm{M}(1 \mu \mathrm{M})$ cytokinin 4PU-30 containing $0.1 \%$ Tween 80 , and $24 \mathrm{~h}$ later, part of the plants were subjected to salt $(\mathrm{NaCl})$ stress with $100 \mathrm{mM}$ $\mathrm{NaCl}$ added to the nutrient medium. Concentrations of all substances were previously defined based on data from preliminary research. Plants were divided into the following variants: 1) control, untreated with 4PU-30; 2) not treated with 4PU-30 plants subjected to $\mathrm{NaCl}$ stress; 3) plants sprayed with 4PU-30;4) cytokinin 4PU-30 treated plants, which were subsequently subjected to $\mathrm{NaCl}$ stress.

Sample preparation and measurements. Samples for measurement were taken $72 \mathrm{~h}$ after $\mathrm{NaCl}$ treatment, when first visible symptoms of injury were observed in salt-stressed pea (Pisum sativum L.) plants.

Relative water content (RWC) was calculated by the following formula:

$$
\mathrm{RWC}(\%)=(\mathrm{FW}-\mathrm{DW}) /(\mathrm{TW}-\mathrm{DW}) \times 100,
$$

where FW is sample fresh weight, TW is sample turgid weight, and DW is sample dry weight (TURNER, 1981).

Biochemical analyses were carried out with fresh plant material homogenised with $0.1 \%(\mathrm{w} / \mathrm{v})$ trichloracetic acid and assayed according to the appropriate methods listed below. The concentration of malondialdehyde (MDA) was determined according to DHINDSA et al. (1981), free proline content was assayed by BATEs et al. (1973) method, and hydrogen peroxide $\left(\mathrm{H}_{2} \mathrm{O}_{2}\right)$ was measured spectrophotometrically according to AleXIEva et al. (2001).

Electrolyte leakage measurements. Four detached leaves from each variant were incubated in $20 \mathrm{ml}$ of distilled water. The conductivity of solutions was measured continuously for $24 \mathrm{~h}$, at $20^{\circ} \mathrm{C}$. The total ion content in tissues was determined after boiling the samples for $15 \mathrm{~min}$ at $100^{\circ} \mathrm{C}$. Results were presented as ratio $\mathrm{k} / \mathrm{k}_{\max }$ versus time, where $\mathrm{k}$ is conductivity at a particular time point, and $\mathrm{k}_{\max }$ is total electrolyte content measured after boiling. Three replicates per variant were measured. Thus, a multiple-point kinetics curve was built. Fitting of experimental data was done by the exponential associate function of software OriginPro 2018 (OriginLab Corporation, Northampton, Massachusetts, USA). The relation $\mathrm{k} / \mathrm{k}_{\max }$ with time is used to measure electrolyte leakage into the distilled water, where leaves were submerged. The kinetic is biphasic with four main parameters derived from the diffusion model described in Kocheva et al. (2014): amplitude $\mathrm{A}_{1}$ and a corresponding time constant $t_{1}$ for the first phase and amplitude $\mathrm{A}_{2}$ and time constant $\mathrm{t}_{2}$ for the second phase. Derivative parameters were obtained by the combination of the four main function parameters and represented duration of the fast phase, named pe$\operatorname{riod} \mathrm{T}$; ion concentration at the moment $\mathrm{T}$ of phase 
equilibrium denoted as $\mathrm{C}(\mathrm{T})$; initial leakage rate, $\mathrm{dC}(0) / \mathrm{dt}$ and leakage rate at the moment $\mathrm{T}, \mathrm{dC}(\mathrm{T}) /$ dt (Kocheva et al., 2014). Three independent experiments were performed with three technical replications each.

Statistical analysis. Presented data are mean values with standard errors ( \pm SE). The significance of differences at $p<0.05$ was analysed using Ducan's multiple range test and statistical software package Statgraphics Plus, version 5.1 for Windows.

\section{RESULTS}

\section{Physiological parameters}

Young pea plants subjected to salt $(\mathrm{NaCl})$ stress had visibly wilted or dried leaves, while pretreatment with 4PU and subsequent exposure to $\mathrm{NaCl}$ did not lead to visual damage symptoms. Regarding the phenotypical changes, the relative water content (RWC) of leaves was assessed. The lowest RWC was measured in $\mathrm{NaCl}$ treated plants (Fig. 1A), followed by cytokinin 4PU-30 pretreated salt-stressed ones. Spraying with 4PU-30 did not significantly af- fect RWC. Compared to controls, 4PU-30 sprayed plants had slightly increased proline levels (Fig. 1B). $\mathrm{NaCl}$ treatment caused a more significant increase in free proline content in the leaves of young pea plants. 4PU-30 treated plants that were subsequently subjected to $\mathrm{NaCl}$ stress had lower proline accumulation compared to salt-stressed but not sprayed with cytokinin pea plants. Accumulation of hydrogen peroxide in pea leaves of 4PU-30 sprayed plants was significantly higher than controls (Fig. 1C). The most significant increase of $\mathrm{H}_{2} \mathrm{O}_{2}$ was found in plants subjected to $\mathrm{NaCl}$ treatment. Pre-treatment with cytokinin and subsequent $\mathrm{NaCl}$ treatment caused lower $\mathrm{H}_{2} \mathrm{O}_{2}$ accumulation compared to salt stress alone. The highest MDA content was determined in salt-stressed pea plants without cytokinin pretreatment. Spraying with 4PU-30 increased MDA slightly compared to controls, and the combination of 4PU-30 and subsequent salt stress had a similar effect (Fig. 1D).

\section{Electrolyte leakage}

Electrolyte leakage kinetics from the leaves of all four variants was followed (controls, sprayed with

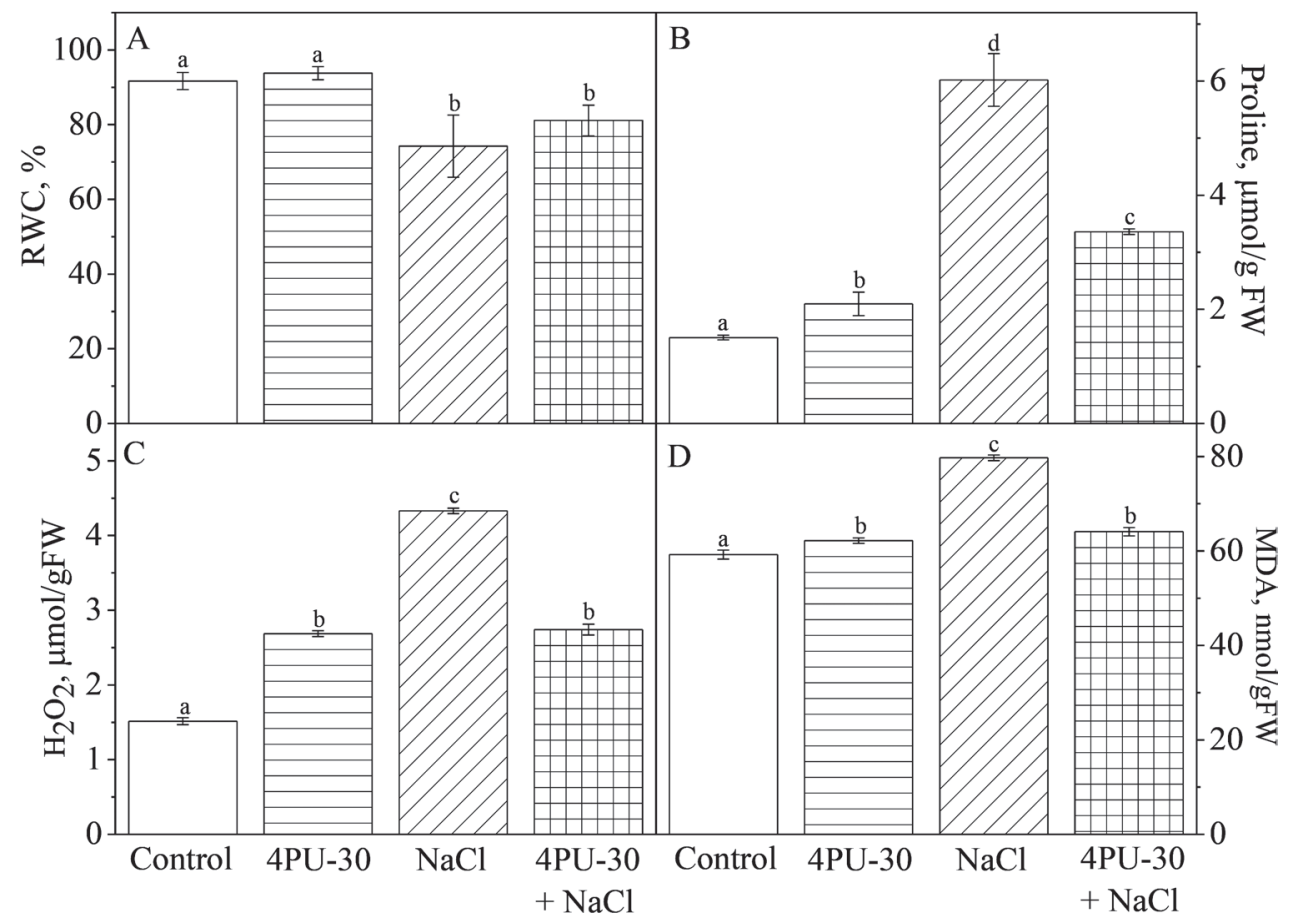

Fig. 1. Impact of salt stress on physiological characteristics of pea seedlings. Relative water content (RWC) (A), proline (B), hydrogen peroxide (C) and malondialdehyde (MDA) (D). Control - without any treatment, 4PU-30 - seedlings sprayed with $1 \mu \mathrm{M} 4 \mathrm{PU}-30+1 \%$ Tween $80, \mathrm{Na} \mathrm{Cl}-100 \mathrm{mM} \mathrm{NaCl}$ added to the nutrient medium, 4PU-30 $+\mathrm{NaCl}-$ plants pretreated with 4PU-30 and $24 \mathrm{~h}$ later subjected to $100 \mathrm{mM} \mathrm{NaCl}$. Data are means $\pm \mathrm{SE}(\mathrm{n}=6)$; letters indicate statistical differences at $p<0.05$ 
4PU-30, $\mathrm{NaCl}$ treated, and salt-stressed after cytokinin pre-treatment), and data were fit with a double exponential function using OriginPro 2018 software (Fig. 2). Two distinct phases of leakage dynamics were observed with different rates: a faster phase connected with passive leakage of ions from the apo-

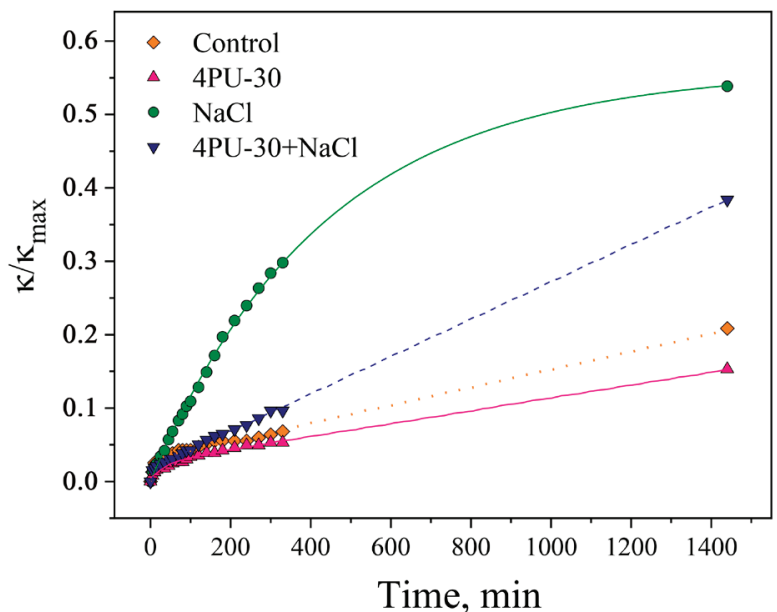

Fig. 2. Ion leakage kinetics from pea leaves of the control treatment (A), plants pretreated with 4PU-30 (B), plants subjected to salt stress with $\mathrm{NaCl}(\mathrm{C})$ and 4PU-30 pretreated plants and subsequently subjected to $\mathrm{NaCl}$ stress (D). The fit of experimental data was done with a two-exponential function using the software OriginPro 2018 plast and simultaneous slower efflux attributed to the selective permeability of cellular membranes.

Four main parameters of the function were derived, namely the amplitudes and time constants of the two separate phases (Fig. 3). The amplitude of the fast phase $\mathrm{A}_{1}$ reflects the ions leaking from the apoplast. Stress did not significantly affect this parameter both in $4 \mathrm{PU}$ treated and $\mathrm{NaCl}$ stressed after cytokinin application, but $\mathrm{NaCl}$ stress pea plants had the highest values of $A_{1}$ (Fig. 3A). The amplitude of the slow phase $\mathrm{A}_{2}$ represents the number of ions leaked through the membrane. It was the highest in controls and $\mathrm{NaCl}$ stressed plants, but showed lower values in both 4PU-30 treated control and cytokinin pretreated and subsequently $\mathrm{NaCl}$ stressed plants (Fig. 3C). The time constant of the fast phase $\left(t_{1}\right)$ had the highest values in salt-stressed plants, while 4PU30 treated were similar to control treatment (Fig. 3B). Cytokinin pretreated plants, which were afterwards subjected to $\mathrm{NaCl}$, showed slightly decreased $\mathrm{t}_{1}$ compared to the control treatment. The slow phase $\left(\mathrm{t}_{2}\right)$ time constant was highest in 4PU-30 treated plants (Fig. 3D). The combination of two treatments, cytokinin followed by $\mathrm{NaCl}$, caused a slight decrease in $\mathrm{t}_{2}$ compared to the control treatment.

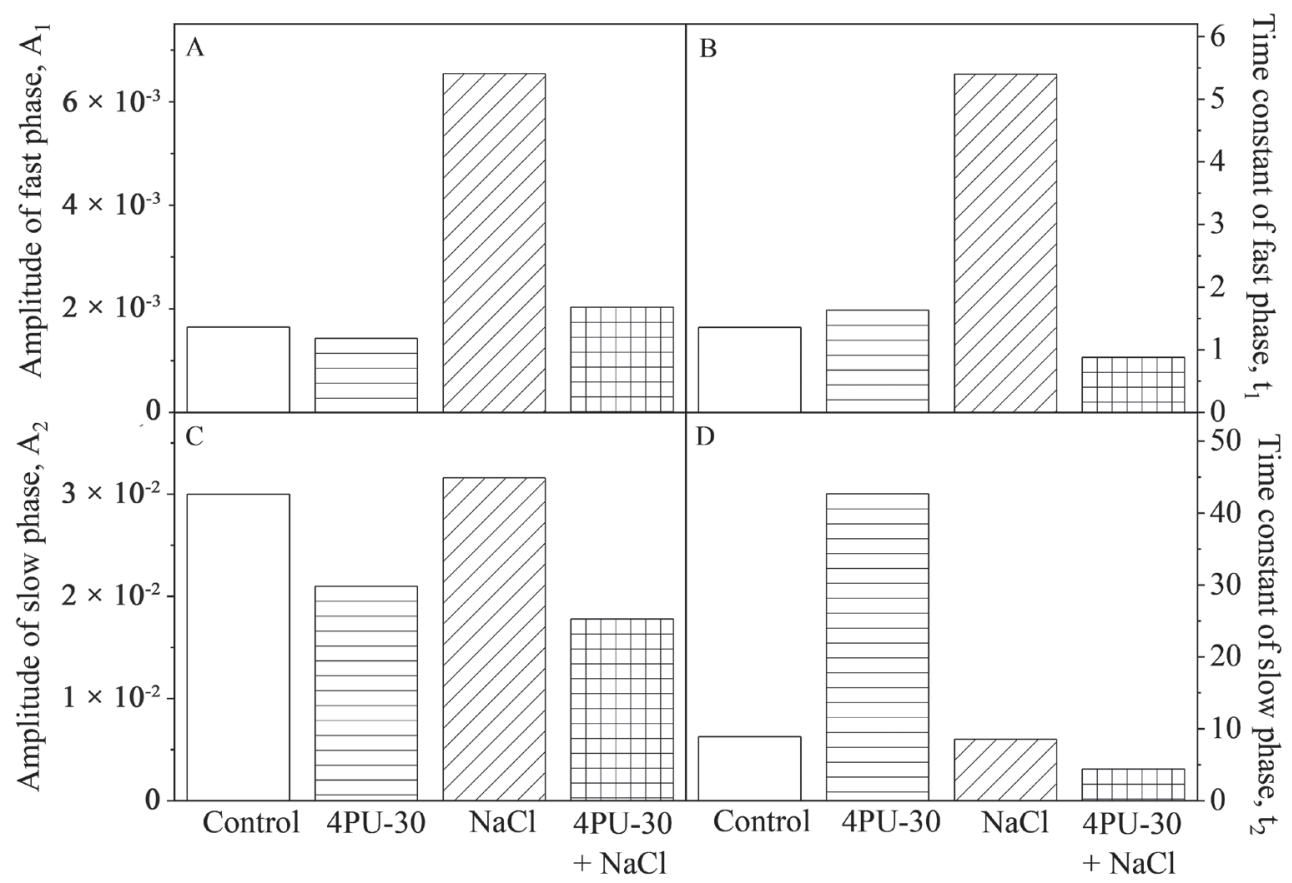

Fig. 3. Main parameters of the diffusion model for electrolyte leakage: amplitude of the first fast phase $\mathrm{A}_{1}$ (A), time constant of fast phase $t_{1}(B)$, the amplitude of the second slow phase $A_{2}(C)$ and time constant of fast phase $t_{2}$ in leaves of pea plants sprayed with 4PU-30, treated with $\mathrm{NaCl}$, pretreated with 4PU-30 and subsequently subjected to $\mathrm{NaCl}$ stress (D), and control treatment 
Four additional parameters were defined as a combination of the main parameters (Fig. 4). Parameter $\mathrm{T}$ is the moment of reaching ion equilibrium of the two phases, and $\mathrm{C}(\mathrm{T})$ is ion concentration at $\mathrm{T}$. The 4PU-30 treated plants reached phase equilibrium very slowly, shown by the highest $\mathrm{T}$ values, and had the highest concentration of leaked ions at the moment T (Fig. 4A and B). Salt stressed cytokinin pretreated pea plants showed a lower concentration of leaked ions at the moment, T, compared to plants only treated with $\mathrm{NaCl}$ (Fig. 4B). Initial leakage rate $\mathrm{dC}(0) / \mathrm{dt}$ was the highest in pretreated salt-stressed plants (Fig. 4C). Cytokinin 4PU-30 spraying resulted in the lowest leakage rates at the beginning and the moment $\mathrm{T}$ of phase equilibrium, $\mathrm{dC}(0) / \mathrm{dt}$ and $\mathrm{dC}(\mathrm{T}) /$ dt, respectively (Fig. 4C and D). Cytokinin pretreated and subsequently subjected to salt stress pea plants had the highest leakage rate at T (Fig. 4D).

\section{DISCUSSION}

Dehydration is often described among the first consequences of many types of abiotic stress, including salinity (NXeLE et al., 2017; MA et al., 2020). A typical early reaction in response to abiotic and biotic stresses is the increase in cellular concentrations of reactive oxygen species (ROS) such as superoxide radicals $\left(\mathrm{O}_{2}^{-}\right)$, hydroxyl radicals $\left(\mathrm{HO}^{-}\right)$, and hydrogen peroxide $\left(\mathrm{H}_{2} \mathrm{O}_{2}\right)$. They are highly detrimental for the cell by causing DNA damage, essential cellular proteins and membrane lipids (NOCTOR \& FOYER, 2016; Noctor et al., 2016; Choudhury et al., 2017). Besides its ROS nature, hydrogen peroxide has multiple other functions in plant cells. Under oxidative stress, it could accumulate to toxic quantities and could thus induce severe damages, eventually leading to cell death. At the same time, $\mathrm{H}_{2} \mathrm{O}_{2}$ is associated with various plant responses - signal transduction, induction of defence genes, cell-wall reinforcing processes, phytoalexin synthesis, etc. (JANKÛ et al., 2019; HasanuzZaman et al., 2020). The highest $\mathrm{H}_{2} \mathrm{O}_{2}$ accumulation was found in salt-stressed pea plants, while 4PU-30 provoked a slight increase in its contents. Cytokinin pretreatment followed by salt stress also induced peroxide accumulation. In this case, increased $\mathrm{H}_{2} \mathrm{O}_{2}$ concentration most probably led to increased antioxidant capacity, although no oxidative damage was estimated based on proline and MDA content. Therefore, this could be an example of the $\mathrm{H}_{2} \mathrm{O}_{2}$ signalling function. However, reactive oxygen species provoke lipid peroxidation chain reactions by attacking the double bonds of the unsaturated fatty

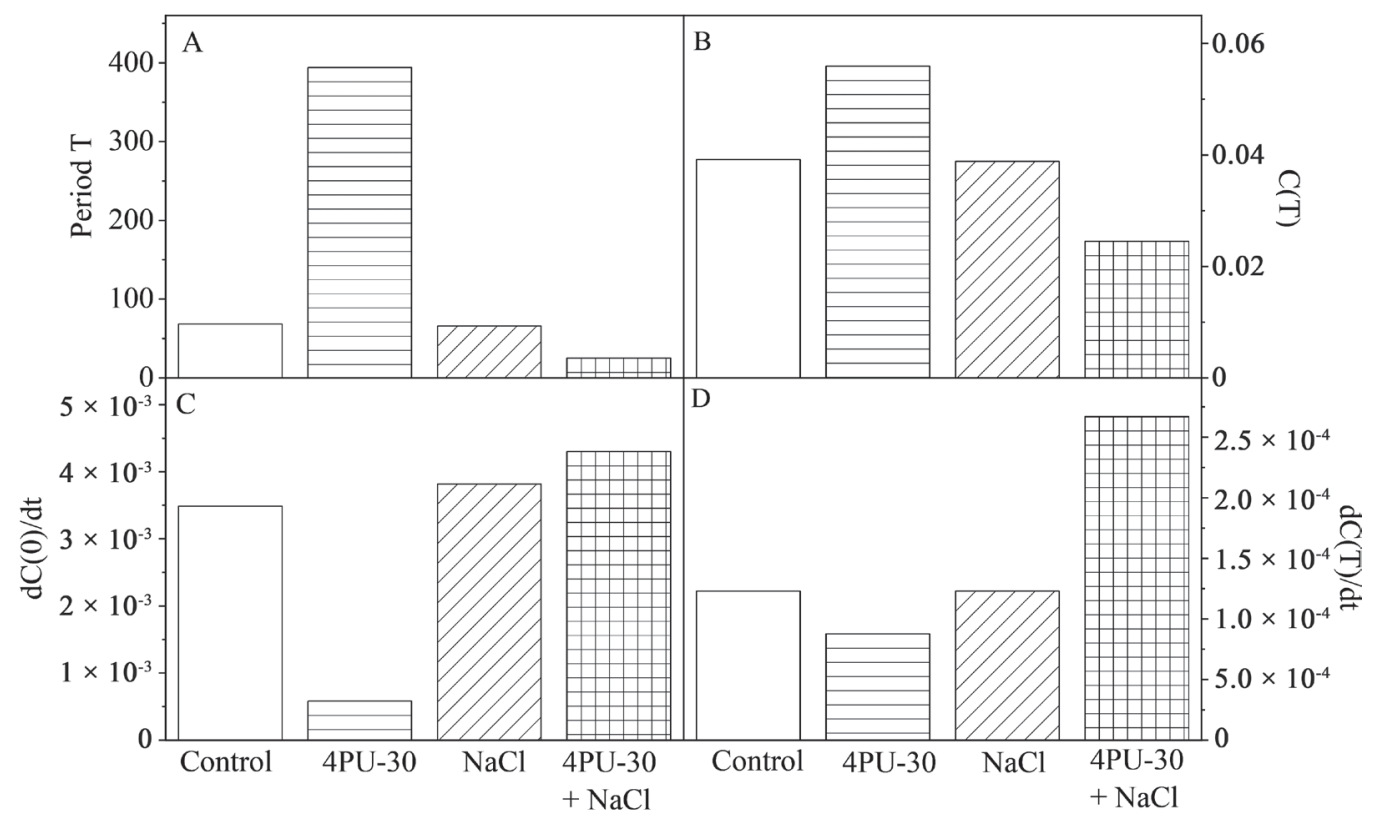

Fig. 4. Additional parameters of the diffusion model for electrolyte leakage: period $\mathrm{T}$ of the fast phase (A), ion concentration at the moment $\mathrm{T}, \mathrm{C}(\mathrm{T})(\mathrm{B})$, initial leakage, $\mathrm{dC}(0) / \mathrm{dt}(\mathrm{C})$, leakage at the moment $\mathrm{T}, \mathrm{dC}(\mathrm{T}) / \mathrm{dt}$ in leaves of pea plants sprayed with 4PU-30, treated with NaCl, pretreated with 4PU-30 and subsequently subjected to $\mathrm{NaCl}$ stress (D), and control treatment 
acids, which are critical components of biomembranes. This leads to the disintegration of membranes and disturbs their natural permeability. Indeed, salt stress induced a significant increase in MDA in the leaves of young pea plants. Malondialdehyde is the final lipid peroxidation product and is a widely used criterion for total lipid peroxidation, biomembrane integrity and oxidative stress assessment (GRIFFITHS et al., 2000; Kirova et al., 2021).

Accumulation of free proline is a widely used indicator for the development of oxidative stress. In many plant species, free proline content increases under unfavourable conditions, both abiotic and biotic. However, no general opinion exists on the exact role of proline, whether it plays a protective role (is has high capability to efficiently detoxify free radicals, and also acts as osmoprotector) or the considerable changes in its concentration are merely a symptom of stress (CZARNocka \& KARPINSKI, 2018). A large amount of data indicated a positive correlation between the increased proline content and the strength of the stress and the presence and extent of adverse changes in the physiological status of plants (KIROVA et al., 2005; KAUR \& AsthiR, 2015). Our results align with data from literature since the highest proline levels were found in salt-stressed pea plants. However, the highest proline accumulation did not reduce the negative effect of stress on membrane stability.

Electrolyte leakage was evidenced in many plant species, various tissue and cell types and was described as a consequence of many types of biotic and abiotic stress, including salinity (DEMIDCHIK et al., 2014). It was described as an unusual reaction in response to stress and was widely used as a stress injury indicator in plant tissues and even as a criterion for plant stress tolerance (ElBAsYoni et al., 2017). By measuring the extent of electrolyte leakage from plant tissues, membrane integrity could be evaluated. Recently, it was proposed that leakage measurement be extended by capturing multiple time-points during the $24 \mathrm{~h}$ incubation (KoCHEVA et al., 2014). Thus, the kinetics of electrolyte leakage was obtained, which could be described by a two-phase exponential curve. The observed two distinct phases represented ion leakage from the two major plant compartments, namely cell walls (forming the so-called apoplast) and cellular membranes (expressing the symplast). Owing to the different permeability for ions that these cellular structures pos- sess, the two phases reflect the contribution of each compartment to the overall ions flux. Rapid leakage consisted of ions occupying intercellular free spaces and cell walls (apoplast), and the slower efflux was due to leakage through plasmalemma and tonoplast. The first phase attributed to the apoplast was fast due to its high ion permeability. The second phase was slower and represented leakage through cellular membranes; thus, the lower efflux rate. The highest parameters $\mathrm{A}_{1}$ and $\mathrm{A}_{2}$ in $\mathrm{NaCl}$ treated pea plants indicated more significant amounts of ion accumulation in the apoplast during salt treatment. The observed increased leakage in salt-stressed plants correlated well with the most significant oxidative damage in this variant due to MDA and $\mathrm{H}_{2} \mathrm{O}_{2}$ accumulation.

The diffusion model to assess electrolyte leakage kinetics was implemented for the first time to evaluate salt stress impact on ion efflux from leaves of young pea plants. It could be concluded that pre-treatment with cytokinin 4PU-30 significantly reduced the oxidative damage of salt-stressed young pea plants, possibly by activating the antioxidant defence system and providing membrane protection against injury.

\section{REFERENCES}

Alexieva V., Sergiev I., Mapelli S., Karanov E., 2001: The effect of drought and ultraviolet radiation on growth and stress markers in pea and wheat. - Plant, Cell and Environment, 24: 1337-1344.

Bates L.S., Walden R.P., Teare I.D., 1973: Rapid determination of free proline in water stress studies. Plant and Soil, 29: 205-207.

Choudhury F.K., Rivero R.M., Blumwald E., MitTLER R., 2017: Reactive oxygen species, abiotic stress and stress combination. - Plant Journal, 90: 856-867. https://doi.org/10.1111/tpj.13299

Czarnocka W., Karpinski S., 2018: Friend or foe? Reactive oxygen species production, scavenging and signalling in plant response to environmental stresses. - Free Radical Biology and Medicine, 122: 4-20. https://doi.org/10.1016/j.freeradbiomed.2018.01.011

Demidснік V., 2015: Mechanisms of oxidative stress in plants: from classical chemistry to cell biology. - Environmental andExperimentalBotany, 109:212-228. https://doi.org/0.1016/j.envexpbot.2014.06.021

Demidchik V., Straltsova D., Medvedev S., Pozhvanov G., Sokolik A., Yurin V., 2014: Stress- 
induced electrolyte leakage: the role of $\mathrm{K}^{+}$-permeable channels and involvement to programmed cell death and metabolic adjustment. - Journal of Experimental Botany, 65(5): 1259-1270. https://doi.org/10.1093/jxb/eru004

Dhindsa R.S., Plumb-Dhindsa P., Thorpe T.A., 1981: Leaf senescence: correlated with increased levels of membrane permeability and lipid peroxidation, and decreased levels of superoxide dismutase and catalase. - Journal of Experimental Botany, 32: 93-101.

ElBasyoni I., Saadalla M., Baenziger S., BockelMANN H., Morsy S., 2017: Cell membrane stability and association mapping for drought and heat tolerance in a worldwide wheat collection. - Sustainability, 9: 1606. https://doi.org/10.3390/su9091606

Giron D., Frago E., Glevarec G., Pieterse C.M.J., DiCKe M., 2013: Cytokinins as key regulators in plant-microbe-insect interactions: Connecting plant growth and defence. - Functional Ecology, 27(3): 599-609. https://doi.org/10.1111/1365-2435.12042

Griffiths G., Leverentz M., Silkowski H., Gill N., SancheZ-Serrano J.J., 2000: Lipid hydroperoxide levels in plant tissues. - Journal of Experimental Botany, 51(349): 1363-1370.

Guo Y., Gan S., 2014: Translational researches of leaf senescence for enhancing plant productivity and quality. - Journal of Experimental Botany, 65: 3901-3913. https://doi.org/10.1093/jxb/eru248

Hai N.N., Chuong N.N., Tu N.H.C., Kisiala A., Hoang X.L., Thao N.P., 2020: Role and regulation of cytokinins in plant response to drought stress. - Plants, 9(4): 422. https://doi.org/10.3390/ plants 9040422

Hasanuzzaman M., Borhannuddin Bhuyan M.H.M., Zulfiqar F., Raza A., Mohsin S.M., Al Mahmud J., Fujta M., Fotopoulos V., 2020: Reactive oxygen species and antioxidant defence in plants under abiotic stress: revisiting the crucial role of a universal defence regulator. - Antioxidants, 9: 681. https://doi.org/10.3390/antiox9080681

IsAYENKOV S.V., 2012: Physiological and molecular aspects of salt stress in plants. Cytology and Genetics, 46: 302-318. https://doi.org/10.3103/S0095452712050040

Jajic I., Sarna T., Strzalka K., 2015: Senescence, stress, and reactive oxygen species. - Plants, 4: 393-411. https://doi.org/10.3390/plants4030393
Jankû M., Luhová L., Petřivalský M., 2019: On the origin and fate of reactive oxygen species in plant cell compartments. - Antioxidants, 8(4): 105. https://doi.org/10.3390/antiox8040105

Kaur G., Asthir B., 2015: Proline: a key player in plant abiotic stress tolerance. - Biologia Plantarum, 59: 609-619. https://doi.org/10.1007/s10535-015-0549-3

Kirova E., Nedeva D., Nikolova A., Ignatov G., 2005: Changes in the biomass production and total soluble protein spectra of nitrate-fed and nitrogen-fixing soybeans subjected to gradual water stress. - Plant Soil Environment, 51(5): 237-242. https://doi.org/10.17221/3580-PSE

Kirova E., Pecheva D., Simova-Stoilova L., 2021: Drought response in winter wheat: protection from oxidative stress and mutagenesis effect. - Acta Physiologiae Plantarum, 43(1): 8. https://doi.org/10.1007/s11738-020-03182-1

Kocheva K.V., Georgiev G.I., Kochev V.K., 2014: An improvement of the diffusion model for assessment of drought stress response in plants. - Physiologia Plantarum, 150(1): 88-94. https://doi.org/10.1111/ppl.12074

Liu Y., Zhang M., Meng Z., Wang B., Chen M., 2020: Research progress on the roles of cytokinin in plant response to stress. - International Journal of Molecular Sciences, 21: 6574. https://doi.org/10.3390/ijms21186574

Ma Y., Dias M.C., Freitas H., 2020: Drought and salinity stress responses and microbe-induced tolerance in plants. - Frontiers in Plant Science, 11: 591911. https://doi.org/10.3389/fpls.2020.591911

Moskova I., Dikova B., Balacheva E., Sergiev I., 2020: Protective effect of plant growth regulators Meia and 4PU-30 against tomato spotted wilt virus (TSWV) on two tomato genotypes. - Comptes Rendus de l'Academie Bulgare des Sciences, 73(11): 15381544. https://doi.org/10.7546/CRABS.2020.11.08

Noctor G., Foyer C.H., 2016: Intracellular redox compartmentation and ROS-related communication in regulation and signalling. - Plant Physiology, 171: 1581-1592. https://doi.org/10.1104/pp.16.00346

Noctor G., Mhamdi A., Foyer C.H., 2016: Oxidative stress and antioxidative systems: recipes for successful data collection and interpretation. Plant, Cell and Environment, 39: 1140-1160. https://doi.org/10.1111/pce.12726 
Nxele X., Klein A., Ndimba B.K., 2017: Drought and salinity stress alters ROS accumulation, water retention, and osmolyte content in sorghum plants. South African Journal of Botany, 108: 261-266. https://doi.org/10.1016/j.sajb.2016.11.003

Sá F.V.S., Brito M.E.B., Silva L.A., Moreira R.C.L., Paiva E.P., Souto L.S., 2020: Exogenous application of phytohormones mitigates the effect of salt stress on Carica papaya plants. - Revista Brasileira de Engenharia Agrícola e Ambiental, 24(3): 170-175. https://doi.org/10.1590/1807-1929/agriambi.v24n3p170-175

Sergiev I.G., Alexieva V.S., Ivanov S.V., Moskova I.I., Karanov E.N., 2006: The phenylurea cytokinin 4PU-30 protects maize plants against glyphosate action. - Pesticide Biochemistry and Physiology, 85(3): 139-146.

Todorov D., Alexieva V., Karanov E., 1998: Effect of putrescine, 4PU-30 and abscisic acid on maize plants grown under normal, drought, and rewatering conditions. - Journal of Plant Growth Regulation, 17(4): 197-203.

TURNER N., 1981: Techniques and experimental approaches for the measurement of plant water status. - Plant and Soil, 58: 339-366.

Veselov D.S., Kudoyarova G.R., Kudryakova N.V., Kusnetsov V.V., 2017: Role of cytokinins in stress resistance of plants. - Russian Journal of Plant Physiology, 64: 15-27. https://doi.org/10.1134/S1021443717010162

Yordanov I., Tsonev T., Goltsev V., Merakchiska M.V., Georgieva K., 1997: Gas exchange and chlorophyll fluorescence during water and high-temperature stresses and recovery. Probable protective effect of urea cytokinin 4-PU30. - Photosynthetica, 33: 423-431.

Yu Z., Duan X., Luo L., Dai S., Ding Z., Xia G., 2020: How plant hormones mediate salt stress responses. - Trends in Plant Science, 25(11): 1117-1130. https://doi.org/10.1016/j.tplants.2020.06.008

\title{
FENILURĖJOS TIPO CITOKININAS GERINA JAUNŲ ŽIRNIŲ PRODUKTYVUMĄ DRUS- KUૃ STRESO SĄLYGOMIS
}

\author{
Irina Moskova, Konstantina Kocheva
}

\section{Santrauka}

Žinoma, kad citokininai didina augalų atsparumą stresui. Šiuo tyrimu buvo siekiama ịvertinti fenilurèjos tipo citokinino (4PU-30) galimą apsaugini poveiki natrio chlorido $(\mathrm{NaCl})$ sukeltam stresui mažinti. Jauni žirnio (Pisum sativum L.) augalai buvo purškiami citokininu 4PU-30, o vèliau apdoroti $\mathrm{NaCl}$. Citokinino 4PU-30 poveikis ląstelių membranų stabilumui buvo vertinamas pagal elektrolitų nutekèjimą iš kontrolinių ir $\mathrm{NaCl}$ stresą patyrusių augalų lapų. Anksčiau sukurta jonų nuotèkio kinetikos modelinè sistema buvo panaudota preliminariai ịvertinti 4PU-30 poveikị augalų reakcijai ị druskingumą. Dèl $\mathrm{NaCl}$ poveikio lapuose šiek tiek sumažèjo vandens kiekis. Prolino, malondialdehido (MDA) ir vandenilio peroksido $\left(\mathrm{H}_{2} \mathrm{O}_{2}\right)$ kaupimasis $\mathrm{NaCl}$ paveiktų augalų lapuose parode, kad kilo oksidacinis stresas, kuri gerokai sušvelnino išankstinis augalų apdorojimas citokininu 4PU-30. Sprendžiant pagal sumažejusi elektrolitų nutekejjimą, lapų paviršių apdorojus 4PU-30, sumažèjo žalingas $\mathrm{NaCl}$ poveikis. Straipsnyje aptartas skirtingas ląstelių sienelių ir plazmalemos vaidmuo jonų nutekejjimui, vykstančiam dèl druskų sukelto streso. 